\title{
Beberapa Permasalahan Dan Pengembangan Metode Pertanggalan
}

Radiokarbon

\section{Faisal Wisjachudin, Agus Taftazani, Bangun Wasito}

Keywords: method, practices, dating, radiocarbon, analysis, archaeology, indonesia

\section{How to Cite:}

Wisjachudin, F., Taftazani, A., \& Wasito, B. (1997). Beberapa Permasalahan Dan Pengembangan Metode Pertanggalan Radiokarbon. Berkala Arkeologi, 17(1), 1-13. https://doi.org/10.30883/jba.v17i1.764

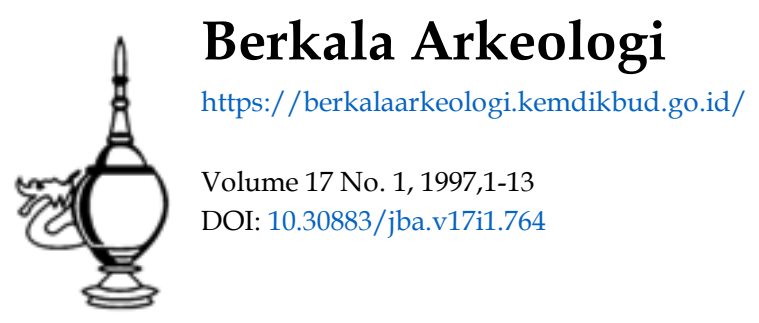

\section{c) (7) (2)}

This work is licensed under a Creative Commons Attribution-NonCommercial-ShareAlike 4.0 International License. 


\title{
BEBERAPA PERMASALAHAN DAN PENGEMBANGAN METODE PERTANGGALAN RADIOKARBON* '
}

\author{
Wisjachudin Faisal, Agus Taftazani, Bangun Wasito \\ (Pusat Penelitian Nuklir Yogyakarta)
}

\section{ABSTRAK}

Telah dilakukan percobaan untuk penelitian dan pengembangan pertanggalan radiokarbon. Dalam hal ini yang perlu dicermati adalah adanya beberapa permasalahan. Permasalahan tersebut antara lain teknik pengambilan sampel, teknik penanganannya di laboratorium, keberadaan standar referensi, adanya kontaminasi pada sampel, fraksinasi isotop, fluktuasi radiokarbon $\left({ }^{14} \mathrm{C}\right)$, keterbatasan sampel dan evaluasi data. Untuk mengatasi permasalahan itu dilakukan penelitian yang mengacu pada perbaikan teknik yang menjadi permasalahan tersebut. Hasil percobaan terhadap sampel kayu, yang dilakukan pencucian dibandingkan dengan yang tidak diberi perlakuan pencucian, menunjukkan adanya perbedaan harga umur sampel kayu sekitar 391 tahun dari umur sesungguhnya sekitar 700 tahun yang lalu. Koreksi delta ${ }^{13} \mathrm{C}\left(\delta^{33} \mathrm{C}\right)$ karena adanya fraksinasi isotop menunjukkan cukup bermakna untuk sampel yang berumur di bawah 30.000 tahun. Koreksi lingkaran pohon (tree ring correction) yaitu koreksi adanya fluktuasi radiokarbon $\left({ }^{14} \mathrm{C}\right)$ pada masa lalu juga memberikan koreksi yang perlu dikaji oleh para peneliti dari bidang arkeologi. Untuk itu diperlukan penanganan sampel dan perlakuan awal yang baik, penentuan harga $\delta^{13} \mathrm{C}$ untuk koreksi adanya fraksinasi isotop karbon, koreksi fluktuasi radiokarbon sedemikian sehingga diperoleh harga pertanggalan yang terkoreksi dengan evaluasi data yang melibatkan berbagai disiplin ilmu, serta upaya penanganan keterbatasan sampel dari lapangan .

\section{ABSTRACT}

Experimental works on a research and development of radiocarbon dating have been carried out. On this occasion several problems have to be concerned. These problems include a sampling technique, its handling in the laboratory, the existence of standard reference material contamination, isotopic fractionation, radiocarbon $\left({ }^{14} \mathrm{C}\right)$ fluctuation, limitation of samples and data evaluation. In order to solve these problems, there have been established research which applied an improvement technique treatment techniques that regarded the

") Makalah ini pernah dibacakan pada Evaluasi Hasil Penelitian Arkeologi 1994 di Palembang 11-16 Oktober 1994 
caution of the problems. The experimental results on wood samples which washed and unwashed showed an age differences of 391 years from its true age of about 700 years ago. Delta ${ }^{13} \mathrm{C}$ correction, due to the availability of isotopic fractionation. shows quite significant to be applied to sample having an age of under 30,000 years. A tree ring correction is a correction due to the existance of their previous radiocarbon dating fluctuation was also giving a correction that need to be studied by archaeologist . For that purpose, there was required a better handling better treatment of the samples.

\section{PENDAHULUAN}

Pertanggalan radiokarbon adalah salah satu metode untuk menentukan umur suatu benda, menetapkan waktu atau urutan kronologisnya dengan cara menentukan kandungan isotop karbon-14 $\left({ }^{14} \mathrm{C}\right)$ nya. Umumnya benda yang berumur sampai dengan \pm 45.000 tahun sebelum sekarang (before present, BP) dapat ditentukan dengan cara ini. Bahkan dengan cara pengkayaan isotop ${ }^{14} \mathrm{C}$ (isotopic enrichment) sedemikian, ada laboratorium yang telah berhasil melakukan penelitian terhadap suatu benda dengan harga pertanggalan mencapai \pm 70.000 tahun, namun ketelitiannya hasilnya rendah. Untuk meneliti perkembangan budaya Asia Tenggara sejak zaman Paleolithik akhir hingga sekarang ${ }^{1}$ dengan batasan umur kurang dari 45.000 tahun tersebut, telah cukup terliput semuanya tanpa menggunakan metode pengkayaan isotop.

Sejak dipakai Libby 1952. pertanggalan radiokarbon telah digunakan selama selama kurang lebih 45 tahun. Selama ini telah ditetapkan prinsip dasar dan teknik atau cara penentuannya. Namun sesuai dengan perkembangannya, jumlah permasalahan yang berhubungan dengan pertanggalan radiokarbon juga bertambah. Diantaranya pengalaman pengumpulan sampel pertanggalan pada lingkungan yang berbeda dan pertanggalan radiokarbon yang ditentukan dengan metode lain dan catatan sejarah.

Pada prinsipnya, metode pertanggalan radiokarbon mudah dimengerti. Seperti diterangkan oleh Libby (1952) dan Terasmae (2), radiokarbon $\left({ }^{14} \mathrm{C}\right)$ diproduksi di atmosfer paling atas oleh reaksi antara radiasi kosmis dan nitrogen. Radiokarbon dikombinasikan dengan oksigen untuk membentuk karbon radioaktif dioksida yang dicampur secara seragam di atmosfer dan digabungkan ke dalam biosfer (mula-mula melalui fotosintesis) dan dipertukarkan dengan hidrosfer menghasilkan kedudukan keseimbangan global radiokarbon permulaan dari aktivitas radiokarbon. Ketika sebuah subsistem (sebuah pohon. kerang laut. dll.) diisolasi dari sistem global (mis. pohon ditebang, atau mati dan dikubur dalam tanah) maka tidak ada lagi radiokarbon $\left({ }^{14} \mathrm{C}\right)$ yang dikonsumsi. 
Akibatnya aktivitas ${ }^{14} \mathrm{C}$ dalam subsistem atau sampel tersebut $\mathrm{i}$ berkurang sesuai dengan hukum peluruhan radioaktif. Dengan diketahuinya tingkat peluruhan i (ditunjukkan oleh waktu paruh isotop) maka aktivitas radiokarbon pada saat $\mathrm{t}$ dapat ditentukan dan umur dari sampel yang telah diisolasi dari keadaan keseimbangan global dapat diukur. Gambaran di atas adalah merupakan "model sederhana" pertanggalan radiokarbon.

Berlakunya model ini tergantung pada beberapa asumsi dasar yaitu:

1. Produksi radiokarbon $\left({ }^{14} \mathrm{C}\right)$ di atmosfer dianggap konstan selama 50.000-100.000 tahun terakhir.

2. Pencampuran, pengambilan, dan penukaran radiokarbon $\left({ }^{14} \mathrm{C}\right)$ di dalam sistem atmosfer-biosfer-hidrosfer telah diseragamkan dan dipercepat dalam skala global sedemikian harga aktivitas awal dianggap sama untuk semua sampel.

3. Tingkat peluruhan radiokarbon adalah konstan.

4. Tidak ada karbon "muda" atau "tua" yang ditambahkan ke dalam sampel selama pengisolasian (dalam keadaan keseimbangan global).

5. Tidak ada fraksinasi isotop yang terjadi yang dapat mengubah perbandingan standar ${ }^{12} \mathrm{C}:{ }^{13} \mathrm{C}:{ }^{14} \mathrm{C}$ pada sampel.

Ahli pertanggalan radiokarbon termasuk Libby, menyadari bahwa meskipun anggapan di atas biasanya sah, tetapi tidak tepat benar, dan riset berikutnya telah mengarahkan kepada penyelidikan permasalahan yang dapat mempengaruhi berbagai aspek metode pertanggalan radiokarbon. Permasalahan ini dapat dikelompokkan dalam beberapa kategori umum antara lain:
A. Pengambilan sampel
B. Kontaminasi sampel
C. Penanganan di laboratorium (teknik laboratorium)
D. Fraksinasi isotop
E. Fluktuasi radiokarbon (pada masa lalu)
F. Standar referensi
G. Keterbatasan jumlah sampel
H. Evaluasi Pertanggalan Radiokarbon

\section{A. Pengambilan Sampel}

Pada waktu pengambilan sampel, para peneliti lapangan (baik arkeolog, geolog serta peneliti lain yang terkait) harus yakin apakah sampel yang akan diteliti tersebut dapat memberikan informasi seperti yang diharapkan. Hal ini diharapakan penentuan dengan metode pertanggalan radiokarbon tersebut, peneliti di laboratorium tidak mungkin melakukan koreksi kesalahan peneliti lapangan. Kesalahan-kesalahan yang biasa terjadi pada waktu pertanggalan adalah belum terpadunya pengumpulan sampel serta waktu pengambilannya. 


\section{B. Kontaminasi Sampel}

Kontaminasi sampel merupakan persoalan yang biasa tetapi dapat menjadi suatu problema yang serius karena sangat boleh jadi pertanggalan tersebut menjadi tidak berguna. Ada sejumlah bukti yang jelas yang menunjukkan pentingnya efek kontaminasi ini. Yang jelas efeknya adalah membuat umur sampel yang ditentukan akan menjadi lebih muda atau lebih tua dari umur sesungguhnya.

\section{Penanganan di laboratorium}

Penanganan yang harus dilakukan bila suatu sampel tiba di lab. pertanggalan radiokarbon, antara lain adalah sampel tersebut perlu diberi nomor sampel dan kode serta dicatat perlakuan yang telah dilakukan sepanjang proses perlakuan awal (pretreatment). Hal ini telah dijelaskan pada tulisan terdahulu (5)). Proses ini meliputi konversi dan tahap-tahap pencacahan, koreksi fraksinasi isotop serta koreksi fluktuasi radiokarbon dimasa lalu.

\section{Fraksinasi Isotop Karbon}

Fraksinasi isotop karbon terjadi selama proses pertumbuhan semua bahan-bahan organik. Guna mengamati fraksinasi isotop karbon, beratus-ratus sampel dari berbagai macam spesies (terutama tumbuhan)) telah dianalisis. Juga telah ditemukan bahwa perbandingan antara isotop dan antara bagian-bagian yang berbeda dari organisme yang sama itu bervariasi.

Aktivitas radiokarbon dari semua standar dan sampel telah direkomendasikan untuk dinormalkan pada rasio standar ${ }^{13} \mathrm{C} /{ }^{14} \mathrm{C}$, atau nilai $\delta^{13} \mathrm{C}$ pada skala $\mathrm{PDB}$ : $-25 \%$ untuk unsur organik dan - $19 \%$ untuk standar asam oxalat (Damon et al., 1978) dan Terasmae (2). Penormalan ini akan berhubungan dengan lingkungan, biologi, dan laboratorium pembelahan isotop. Karena itu pemakai harus waspada terhadap permasalahan ini.

\section{E. Fluktuasi radiokarbon}

Fluktuasi radiokarbon dalam sistem atmosfer-biosfer-hidrosfer diantisipasi selama bertahun-tahun diawal pertanggalan radiokarbon. Antisipasi ini membutuhkan teknologi, teori, dan perkembangan empiris dari berbagai disiplin ilmu (termasuk astrofisik, oceanografi, dan geokimia). Ini diperlukan sebelum beberapa hipotesis dapat diuji dan akhimya dijumlah bagian demi bagian.

Menurut Damon et ai. (1978) yang dikutip Terasmae (2) fluktuasi radioaktif disebabkan antara lain oleh :

1. Variasi tingkat produksi radiokarbon di atmosfer yang disebabkan oleh:

a. Variasi aliran sinar kosmis dalam sistem matahari. (Sinar kosmis keluar dari "supernovae" dan fenomena perbintangan lain dan modulasi "interstellar" aliran sinar kosmis). 

b. Pengaturan fluks sinar kosmis karena aktivitas matahari.
c. Pengaturan fluks sinar kosmis oleh perubahan di medan magnit bumi.
d. Produksi radiokarbon oleh tubrukan meteor dengan bumi.
e. Produksi radiokarbon akibat pengujian senjataa nuklir dan teknologi nuklir.

2. Variasi tingkat perubahan radiokarbon di antara berbagai tempat penyimpanan geokimia dan perubahan kandungan relatif karbon dioksida di tempat penyimpanan.
a. Pengontrolan kemampuan dapat dilarutkan dan tidak dapat dilarutkannya $\mathrm{CO}_{2}$ sesuai dengan waktu variasi suhu.
b. Akibat variasi ketinggian laut terhadap sirkulasi laut dan kapasitasnya.
c. Asimilasi $\mathrm{CO}_{2}$ oleh biosfer bumi dalam perbandingan terhadap biomassa dan konsentrsi $\mathrm{CO}_{2}$, dan ketergantungan $\mathrm{CO}_{2}$ terhadap suhu. kelembaban, dan aktivitas manusia.
d. Ketergantungan asimilasi $\mathrm{CO}_{2}$ oleh biosfer laut tergantung kepada suhu dan kadar garam laut, tersedianya nutrisi, air yang kaya $\mathrm{CO}_{2}$, dan kekeruhan lapisan laut yang bercampur.

3. Variasi jumlah total karbon dioksida dalam atmosfer, biosfer, hidrosfer.

a. Perubahan kecepatan pemasukan $\mathrm{CO}_{2}$ ke dalam atmosfer oleh vulkanisme dan psoses-proses lain yang mengakibatkan penghilangan gas $\mathrm{CO}_{2}$ dari litosfer.

b. Berbagai tempat penyimpanan endapan bertindak sebagai penampung $\mathrm{CO}_{2}$ dan ${ }^{14} \mathrm{C}$. Kecenderungan untuk merubah kecepatan sedimentasi menyebabkan perubahan kandungan $\mathrm{CO}_{2}$ total di atmosfer.
c. Pembakaran bahan bakar fosil oleh industri milik manusia dan aktivitas domestik.

Tak ada lagi keraguan bahwa fluktuasi radioaktif alam, sesungguhnya, terjadi melalui waktu, dan ditambah pula oleh yang disebabkan aktivitas manusia seperti pembakaran bahan bakar dan pengujian senjata-senjata nuklir. Namun demikian, sebab-sebab, besar dan peredaran fluktuasi ${ }^{14} \mathrm{C}$ alam yang mungkin, masih menjadi obyek riset aktif, sebagai contoh, kemungkinan fluktuasi ini dengan aktivitas matahari dan perubahan iklim.

Dendrokronologi dan pertanggalan radiokarbon telah mempunyai hubungan panjang sebab baris lingkaran pohon telah memberikan skala waktu yang dapat digunakan untuk mengukur aktivitas radioaktif. Meskipun fluktuasi ini meliputi sebuah permasalahan dalam pertanggalan radiokarbon. tetapi tidak membuat metode itu tidak berlaku sebab jika alam fluktuasi telah dikenal baik. fluktuasi itu dapat dikoreksi dalam penghitungan umur radiokarbon. 


\section{F. Referensi standar}

Referensi sandar diperlukan dalam pertanggalan radiokarbon untuk kalibrasi dan pengecekan periodik terhadap pengoperasian peralatan laboratorium secara benar, maupun untuk penghitungan pertanggalan radioaktif yang dilaporkan kepada pemakai. Penggunaan standar referensi menjamin keseragaman analisis pertanggalan radiokarbon dalam laboratorium tertentu dan memberikan dasar umum untuk memperbandingkan pertanggalan-pertanggalan radiokarbon yang dihasilkan oleh berbagai laboratorium.

Sebagai standar pertanggalan radiokarbon telah disepakati oleh para pakar pertanggalan radiokarbon sedunia yaitu menggunakan asam oksalat yang diprodusi oleh U.S. National Bureau of Standards. Standar aktivitas karbon-14 didefinisikan sebagai $95 \%$ dari aktivitas karbon-14 dalam Standar Asam Oksalatat NBS.

\section{G. Keterbatasan jumlah sampel}

Salah satu kendala yang ada di laboratorium adalah terbatasnya jumlah sampel yang beratnya kurang dari batas berat yang diharapkan adalah kira-kira 5 sampai 10 gram karbon. Bahkan menurut Pearson dkk (1977) yang dikutip oleh Terasmae (2) digunakan sampel dengan berat 180-200 gram untuk memperoleh ketepatan yang tinggi dalam pertanggalan radiokarbon, karena jumlah (ukuran) sampel yang tidak tepat dapat mempengaruhi hasil pertanggalan radiokarbon. Untuk itu perlu diupayakan sedemikian sehingga diperoleh hasil sintesis dengan volume yang memenuhi syarat, salah satunya dengan cara menambahkan $\mathrm{CO}_{2}$ teknis kemudian disintesis bersama-sama $\mathrm{CO}_{2}$ hasil pembakaran sampel yang jumlahnya kecil hingga diperoleh benzen yang mencukupi atau dengan cara menambah benzen "mati" ke dalam benzen hasil sintesis. Sedangkan cara lain dapat dilakukan dengan menggunakan alat spektrometer massa akselerator, tetapi alat ini hanya dipunyai oleh beberapa laboratorium tertentu saja.

\section{H. Evaluasi Pertanggalan Radiokarbon}

Pada evaluasi ini perlu adanya kerjasama peneliti dengan berbagai disiplin ilmu, karena ruang lingkup permasalahan metode pertanggalan radiokarbon yang menyangkut berbagai disiplin ilmu, mensyaratkan keikutsertaan keahlian dari beberapa bidang penelitian.

\section{TATA KERJA}

Bahan :

1. Sampel Kayu ( PRYW9204.PRYW9104, PRYW9105)

2. Sampel Tulang (PRYB9007. PRYB9011)

3. Sampel Arang (PRYC9307) 
4. Asam Oksalat (NBS 4990 C)

5. Litium (LCA, USA)

6. Es kering, gas $\mathrm{CO}_{2}$, gas $\mathrm{O}_{2}$ (Aneka Gas)

7. Nitrogen Cair (PPNY)

8. Benzen, $\mathrm{H}_{3} \mathrm{PO}_{4}$ (PA, Merck)

9. PPO, POPOP(Packard)

10. Kromium Alumina(Kal-Chemie)

11. Glass wool, quartz wool (Heraeous)

12. Ascarite II (Thomas Scientific)

13. $\mathrm{HCl}, \mathrm{H}_{2} \mathrm{SO}_{4}, \mathrm{KMnO}_{4}, \mathrm{P}_{2} \mathrm{O}_{5}, \mathrm{NaOH}, \mathrm{CuO}$ (PA, Fisher)

II. PERAlatan

1. Benzen Synthesizer (Task.Inc.USA)

2. Liq. Sci. Counter (Packard $2000 \mathrm{CA} / \mathrm{LL}$ )

3. Spektrometer Massa (VG ISOGAS SIRA 9)

4. Peralatan ekskavasi (Balai Arkeologi)

\section{CARA KERJA}

Langkah pertama adalah perlakuan awal berupa pencucian sampel dengan air biasa, dibersihkan dari pengotor-pengotor terutama tanah, dibilas dengan akuades. Kemudian dilakukan perlakuan pencucian dengan metoda asam-basa-

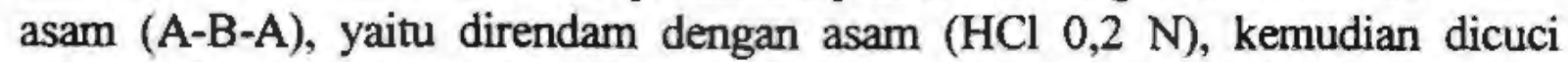
dengan akuades, diikuti dengan basa $(\mathrm{NaOH} 0,2 \mathrm{~N})$ dan dicuci dengan akuades, diakhiri dengan pencucian asam sama dengan yang tersebut di atas. Khusus untuk sampel kayu (PRYW 9204) ada 2 sampel, salah satunya hanya dicuci biasa tidak diberi perlakuan seperti di atas (pencucian A-B-A), sedangkan sampel yang lain diberi perlakuan seperti diatas. Sampel PRYW 9204 ini untuk membuktikan seberapa jauh pengaruh dekontaminasi (pencucian). Sedangkan sampel yang lain untuk membuktikan seberapa jauh penganuh koreksi delta C-13 $\left(\delta^{13} \mathrm{C}\right)$ terhadap berbagai umur sampel. Setelah dikeringkan pada suhu $125^{\circ} \mathrm{C}$, sampel tersebut ditimbang \pm 10 gram, dan siap untuk dibakar hingga (disintesis) menjadi benzen $\left(\mathrm{C}_{6} \mathrm{H}_{6}\right)$ termasuk standar asam oksalat SRM4990C.

Setelah disiapkan sintilator dengan wadah vialnya maka analisis dilanjutkan dengan pencacahan radioaktivitas ${ }^{14} \mathrm{C}$ dengan menggunakan alat pencacah kelip cair latar rendah (low level liquid scintillation counter).

Dengan membandingkan aktivitas jenis ${ }^{14} \mathrm{C}$ dari cuplikan dengan standar asam oksalat tersebut maka akan dapat dihitung pertanggalan (umur) cuplikan. 


\section{HASIL DAN PEMBAHASAN}

Pengelolaan sampel untuk pertanggalan radiokarbon harus cermat, sebagai contoh adalah pada waktu pengambilan sampel di lapangan : arang kayu yang digali pada pemukiman suatu situs tertentu. Semula diduga bahwa arang tersebut seumur dengan lahannya. tetapi setelah dilakukan penelitian lebih lanjut temyata bahwa arang tersebut adalah dari timbunan kayu peninggalan atau pokok kayu dari pohon yang sudah tua umurnya, bukannya berasal dari pembakaran ranting-ranting cabang-cabang pepohonan. Sehingga arang tersebut memberikan hasil pertanggalan yang lebih besar dari umur sesungguhnya.

Untuk itu perlu adanya kejelasan pada saat pengambilan serta pengumpulan sampel tersebut, antara lain :

- Apakah sampel diambil dari tingkat-tingkat atau lapisan-lapisan yang sudah jelas.

- Apakah sampel yang diambil dari daerah yang telah mengalami proses geologi alam, atau belum.

- Apakah sampel tersebut berasal dari tempat lain karena pengaruh air atau angin, dan lain-lain.

Pertanyaan-pertanyaan tersebut hanya bisa diamati di lapangan, peneliti di laboratorium pertanggalan radiokarbon tidak dapat menjawab pertanyaan tersebut di atas. Sehingga secara seksama dari sampel yang berhubungan dengan keadaan fisik perlu data yang akurat dari peneliti lapangan.

Setelah harga pertanggalan suatu sampel telah dihitung maka perlu dilakukan koreksi akibat adanya fraksinasi isotop yaitu dengan menganalisis harga delta ${ }^{13} \mathrm{C}$ yang dirumuskan seperti tersebut di bawah ini :

$$
\delta^{13} \mathrm{C}=\frac{\left({ }^{13} \mathrm{C} /{ }^{12} \mathrm{C}\right)_{\mathrm{s}}-\left({ }^{13} \mathrm{C} /{ }^{12} \mathrm{C}\right)_{\text {sd }}}{\left({ }^{13} \mathrm{C} /{ }^{12} \mathrm{C}\right)_{\text {sed }}} \times 10^{3} \text { permil }
$$

Asam oksalat standar (NBS 4990C) perlu dilakukan koreksi $\delta^{13} \mathrm{C}$ karena pada saat proses pembakaran menjadi benzene terjadi fraksinasi isotop , sehingga harga aktivitas ${ }^{14} \mathrm{C}$ oksalat terkoreksi :

$$
A_{0}=0,95 A_{\text {ax }}\left[1-\frac{2\left(19+\partial^{13} C\right)}{1000}\right]
$$

dari percobaan yang dilakukan 3 kali berturut-turut harga $\delta^{13} \mathrm{C}=-17,8 \pm$ 0,78 permil. Harga $\delta^{13} \mathrm{C}$ ini dimasukkan ke rumus (1) maka harga $\mathrm{S}_{\text {std }}$ aktivitas spesifik asam oksalat standar adalah $A_{0}$ dibagi berat benzene yang terbentuk. Maka harga $S_{\text {std }}$ tersebut dimasukkan rumus (2) di bawah ini : 


$$
t=8033 \ln \frac{S_{s t d}}{S_{s m p}}+8033 \ln \frac{1}{1-\frac{2\left(d^{i 3} C+25\right)}{1000}}
$$

$\mathrm{S}_{\text {gdd }} \quad=$ Aktivitas spesifik asam oksalat standard.

$\mathrm{S}_{\mathrm{s}} \quad=$ Aktivitas spesifik dari sampel.

$\mathrm{t} \quad=$ Umur dalam BP (before present)

BP = "Tahun sebelum saat ini", sedangkan

"saat ini" adalah tahun 1950.

Tabel 1. Perbedaan Harga Pertanggalan Dengan dan Tanpa Pencucian

\begin{tabular}{|l|l|l|c|}
\hline Sampel & $\begin{array}{l}\text { Harga } \\
\text { Pertanggalan } \\
\text { Tanpa } \\
\text { Pencucian }\end{array}$ & $\begin{array}{l}\text { Harga } \\
\text { Pertanggalan } \\
\text { Dengan } \\
\text { Pencucian }\end{array}$ & $\begin{array}{l}\text { Perbedaan } \\
\text { Antara } \\
\text { Keduanya }\end{array}$ \\
\hline $\begin{array}{l}\text { PRYW } \\
9204\end{array}$ & $\begin{array}{l}1239 \pm 63 \mathrm{BP} \\
(711 \pm 63 \mathrm{M})\end{array}$ & $\begin{array}{l}1630 \pm 57 \mathrm{BP} \\
(320 \pm 57 \mathrm{M})\end{array}$ & 319 \\
\hline
\end{tabular}

Dari tabel 1 terlihat bahwa harga pertanggalan sampel kayu (PRYW 9204) yang dengan pencucian A-B-A umumya $1630 \pm 57 \mathrm{BP}=320 \pm 57$ Masehi, sedangkan yang tanpa perlakuan (pencucian A-B-A) umurnya $1239 \pm 63=$ $711 \pm 63$ Masehi. Jelas bahwa sampel kayu yang tanpa pencucian A-B-A hasil pertanggalan (umurnya) menjadi lebih muda dibandingkan bila diberi perlakuan (pencucian asam, basa, asam).

\section{Tabel 2. Koreksi Fraksinasi Isotop}

\begin{tabular}{||l|l|l|l||}
\hline Sampel & \multicolumn{1}{|c|}{$d^{13} \mathrm{C}$} & \multicolumn{1}{|c|}{$\begin{array}{l}\text { Harga } \\
\text { Pertanggalan }\end{array}$} & $\begin{array}{l}\text { Harga } \\
\text { Koreksi }\end{array}$ \\
\hline PRYB9007 & $-11,56$ & $1467 \pm 61$ & 219 \\
\hline PRYB9011 & $-13,63$ & $1545 \pm 143$ & 185 \\
\hline PRYW9104 & $-23,77$ & $43566 \pm 282$ & 21 \\
\hline PRYW9105 & $-32,30$ & $1360 \pm 83$ & 117 \\
\hline
\end{tabular}

Dari data hasil percobaan (tabel 2), terlihat sampel pertama dan kedua (PRYB9007 dan PRYB 9011) adalah sampel tulang sedangkan sampel keempat adalah sampel kayu, ketiganya hidup pada abad 14 - 15, mempunyai koreksi fraksinasi isotop cukup bermakna yaitu di atas 117 tahun, sedangkan untuk sampel ketiga (PRYW9104) berupa sampel kayu dengan umurnya 43.566 (lebih 30.000 ) tahun harga koreksi fraksinasinya tidak cukup bermakna (21 tahun). 
Setelah dilakukan koreksi fraksinasi isotop maka perlu dilakukan koreksi karena fluktuasi radiokarbon pada masa lampau (pada saat sampel "masih hidup") yaitu dengan koreksi lingkaran pohon (tree ring correction). Plicht dkk (10) telah menulis suatu program yang sangat berguna untuk keperluan tersebut sebagai contoh akan penulis sampaikan hasil program itu seperti yang terlihat pada gambar 1

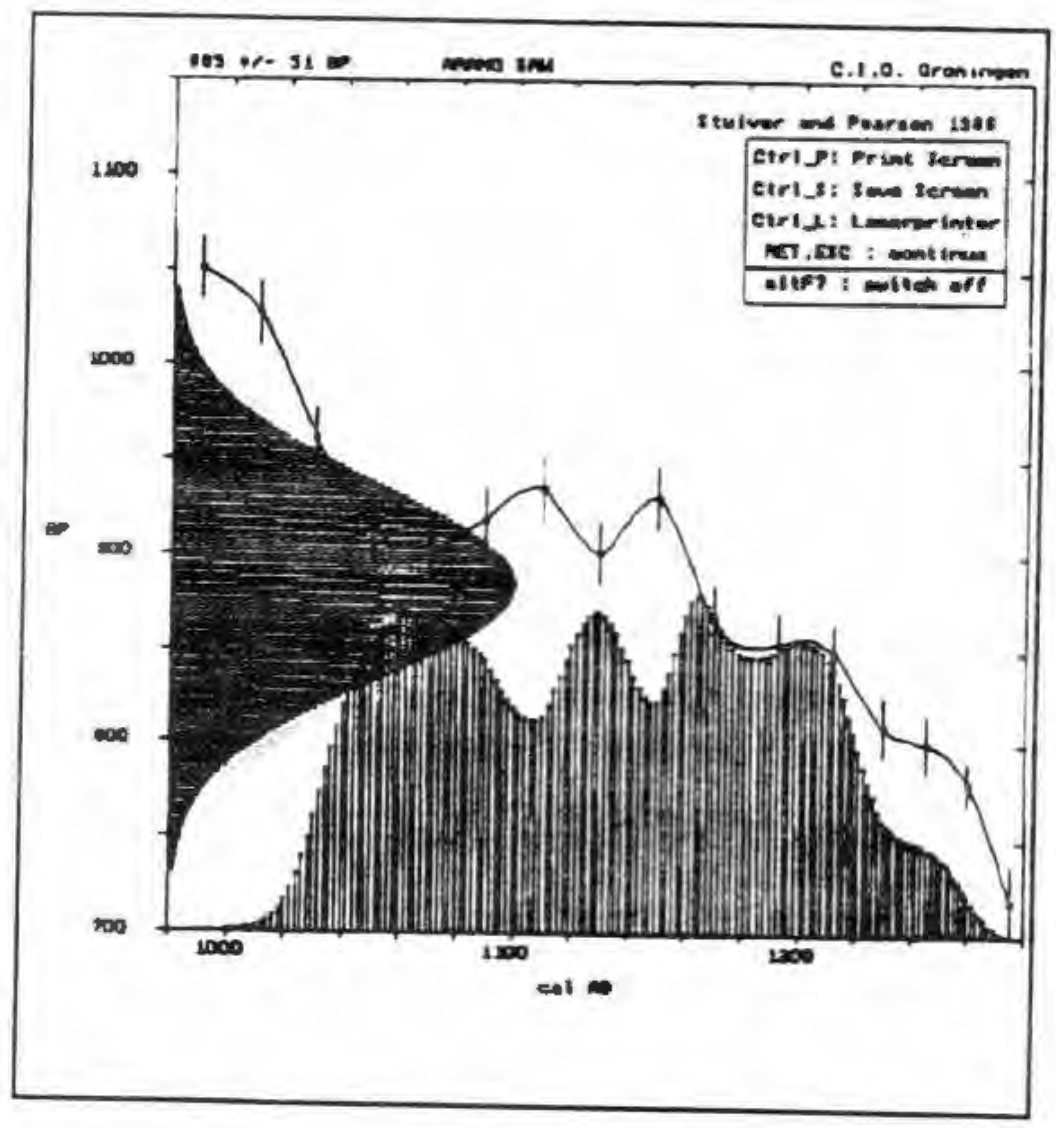

Gambar 1. Distribusi Data Pertanggalan Dengan Koreksi Lingkaran Pohon

Dalam gambar 2 (Hasil Pertanggalan Yang Terkoreksi yang diperbesar) terlihat bahwa yang di sebelah kiri adalah distribusi umur sampel setelah dikoreksi dengan pengaruh fraksinasi isotop yaitu $885 \pm 51 \mathrm{BP}(1064 \pm 51 \mathrm{M})$, sedangkan yang di sebelah kanan atas distribusi umur sampel (kurva tanpa diarsir) adalah hasil pengukuran koreksi lingkaran pohon dari tiap lingkaran yang diambil sedikit kemudian ditentukan umumya dengan alat spektrometer massa akselerator. Kurva tersebut merupakan rekaman komposisi isotop karbon dari waktu ke waktu pada masa yang lampau. Sedangkan kurva yang paling bawah adalah distribusi pertanggalan setelah dikoreksi dengan fluktuasi radiokarbon lingkaran pohon.. Data yang diperoleh bisa dalam tingkat keyakinan $68,3 \%$ (1 sigma) atau dalam tingkat keyakinan 95,4\% ( 2 sigma ). 
Hasil yang diperoleh berdasarkan gambar 2 tersebut terlihat untuk 1 sigma (garis putus-putus bagian bawah yang memotong kurva) harganya berkisar $1044 \mathrm{AD}$ (Masehi) sampai dengan $1214 \mathrm{AD}$ (Masehi) sedangkan bila kita memilih 2 sigma (garis putus-putus bagian atas yang memotong kurva) maka harga pertanggalannya berkisar dari $1028 \mathrm{M}$ sampai dengan $1244 \mathrm{M}$. Padahal bila tanpa koreksi lingkaran pohon hanya berkisar $1061 \pm 51$ Masehi. Sehingga perlu kajian dari arkeolog mengenai interpretasi serta evaluasi data tersebut ditinjau dari sudut arkeologi.

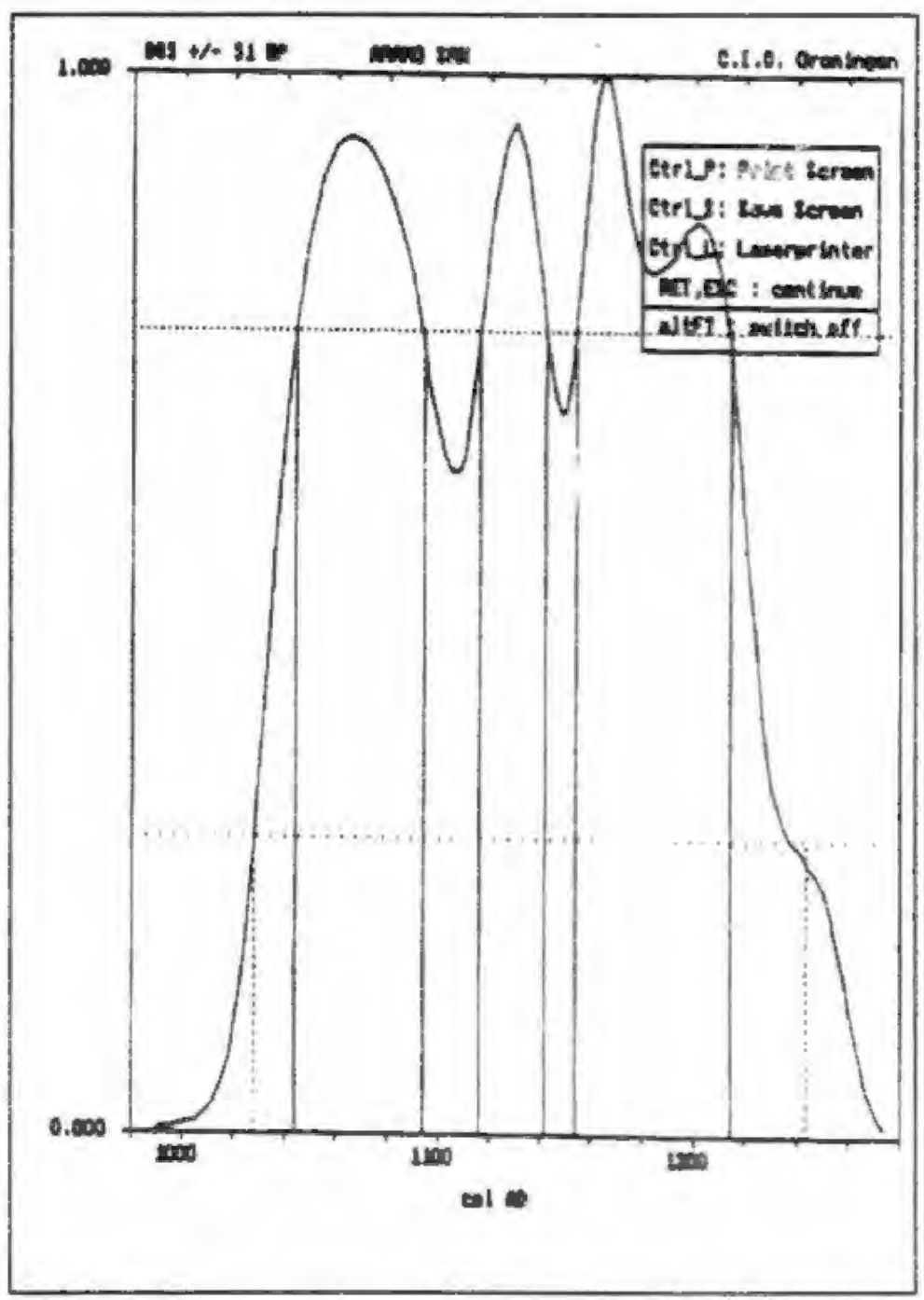

Gambar 2. Hasil Pertanggalan Yang Terkoreksi (Diperbesar)

Disinilah peranan kerjasama peneliti dengan berbagai disiplin ilmu, karena ruang lingkup permasalahan metode pertanggalan radiokarbon yang menyangkut berbagai disiplin ilmu, mensyaratkan keikutsertaan keahlian dari beberapa bidang penelitian. Mengenai keterbatasan jumlah (ukuran) sampel ada beberapa kendala. Bila ukuran sampel tidak cocok akan mempengaruhi penentuan umur (pertanggalan) radiokarbon. Pada tulisan kami terdahulu (6) bahwa metoda pengenceran menggunakan $\mathrm{CO}_{2}$ dan benzen mati "dead benzene" hanya bermakna (signifikan) pada cuplikan yang umurnya relatif tua. 
Dalam riset arkeologi seringkali penelitinya kesulitan dalam mengambil keputusan apakah memberikan satu atau lebih obyek yang berharga dalam jumlah sampel yang memadai (beratnya) untuk digunakan analisis pertanggalan radiokarbon (yang akan merusak sampel tersebut padahal jumlahnya sangat terbatas) atau memberikan sampel yang sangat kecil tetapi tidak dapat memberikan keakuratan pertanggalan yang diinginkan. Ada beberapa perkembangan yang menggembirakan dalam pertanggalan radiokarbon yaitu penggunaan teknik nuklir fisik untuk penghitungan atom radiokarbon secara langsung dalam sampel, lebih dari pada kejadian fraksinasi (Muller, 1977; Litherland, 1979 dan Terasmae (2)).

Mungkin keuntungan terbesar dari metode baru ini adalah kemampuan menggunakan sampel yang sangat kecil (hanya beberapa miligram) untuk pertanggalan dan memecahkan satu diantara problem yang sukar dari pertanggalan radiokarbon yang konvensional. Kemajuan lain adalah pengayaan isotop radiokarbon oleh difusi thermal yang memperluas kisaran pertanggalan menjadi kira- kira 75.000 tahun BP (Grootes, 1978; Stuiver et al., 1978 dan Terasmae (2)). Namun demikian, teknik ini agak sukar, pengkonsumsian waktu, serta kurang akurat.

\section{KESIMPULAN}

Dari data di atas maka perlu penanganan sampel dan perlakuan awal yang baik, penentuan harga delta ${ }^{13} \mathrm{C}$ untuk koreksi adanya fraksinasi isotop karbon, koreksi fluktuasi radiokarbon sehingga diperoleh harga pertanggalan yang terkoreksi serta upaya penanganan keterbatasan sampel dari lapangan serta kerjasama peneliti dengan berbagai disiplin ilmu, karena ruang lingkup permasalahan metode pertanggalan radiokarbon yang menyangkut berbagai disiplin ilmu, mensyaratkan keikutsertaan keahlian dari beberapa bidang penelitian untuk evaluasi serta interpretasi data maupun menangani kendala lain yang tidak bisa dipecahkan oleh peneliti dalam bidang yang terbatas. 


\section{KEPUSTAKAAN}

Faisal, W., Lahagu. F., Dewi. K.,Pujiyono. P., 1991. Penerapan metode penanggalan radiocarbon dating dengan cara pembakaran kering, Pertemuan dan Presentasi Ilmiah Penelitian Dasar Pengetahuan dan Teknologi Nuklir, PPNY-BATAN, Yogyakarta.

Faisal, W., Lahagu. F.. Dewi, K., Pujiyono, P., 1991. Penentuan umur (penanggalan) cuplikan kerang dengan metode radiocarbon dating, Prosiding Pertemuan dan Presentasi Ilmiah Penelitian Dasar Pengetahuan dan Teknologi Nuklir, PPNY-BATAN, Yogyakarta.

Faisal, W., Pujiyono, P., Prayogo, I., Susetyo, W., Djiyono., Siswanto., 1993. Pertanggalan Radiokarbon Dari Cuplikan Dalam Jumlah Kecil, Prosiding Pertemuan dan Presentasi Ilmiah Penelitian Dasar Pengetahuan dan Teknologi Nuklir, PPNY-BATAN, Yogyakarta.

Gunter Faure,, 1977. Principles of Isotopic Geology. The Ohio State University, Colombus, Ohio.

Jacob, T.,1971. Kepurbaan Manusia di Asia Tenggara dan Sekitarnya, Berkala Ilmu Kedokteran Gadjah Mada, Djilid III, No.4, Yogyakarta.

Libby, W.F.,1955. Radiocarbon Dating, University of Chicago Press, Phoenix Science Series, Chicago.

Noakes. J.E.,1993. Komunikasi Pribadi.

Plicht, J.V.D., Mook, W.G.1988. Calibration of Radiocarbon Dating Ages By Computer, Centre for Isotope Research, University of Groningen, Groningen, Netherland.

Shepard, J.C., 1975. Radiocarbon Dating Primer, Washington University Collage of Engineering Bulletin 338, Engineering Extention Service, Pullmen Washington.

Terasmae, J.,1981. Radiocarbon Dating, Some Problem and Potential Development in Paleonthology and Stratigraphy Vol.7. 